\title{
Effect of Hepatitis C Treatment on Renal Function in Liver Transplant Patients
}

\author{
Mohamed Shoreibah ${ }^{1}$, John Romano*2 ${ }^{2}$ Omar T. Sims ${ }^{3,4,5}$, Yuqi Guo ${ }^{6}$, DeAnn Jones ${ }^{7}$, \\ Krishna Venkata ${ }^{2}$, Vishnu Kommineni ${ }^{2}$, Jordan Orr $^{8}$, Paul Fitzmorris ${ }^{1}$ and Omar I. Massoud ${ }^{1}$ \\ ${ }^{1}$ Division of Gastroenterology \& Hepatology, School of Medicine, University of Alabama at Birmingham, Birmingham, AL, USA; \\ ${ }^{2}$ Department of Internal Medicine, School of Medicine, University of Alabama at Birmingham, Birmingham, AL, USA; ${ }^{3}$ Department \\ of Social Work, College of Arts and Sciences, University of Alabama at Birmingham, Birmingham, AL, USA; ${ }^{4}$ Department of Health \\ Behavior, School of Public Health, University of Alabama at Birmingham, Birmingham, AL, USA; ${ }^{5}$ Center for AIDS Research, \\ School of Medicine, University of Alabama at Birmingham, Birmingham, AL, USA; ${ }^{6}$ School of Social Work, University of Alabama, \\ Tuscaloosa, AL, USA; ${ }^{7}$ Department of Pharmacology, University of Alabama at Birmingham, Birmingham, AL, USA; ${ }^{8}$ Division of \\ Gastroenterology and Hepatology, Department of Medicine, Vanderbilt University, Nashville, TN, USA
}

\begin{abstract}
Background and Aims: Hepatitis C Virus (HCV) is uniformly recurrent after liver transplant (LT) and recurrence is associated with an increased risk of mortality. Immunosuppressive medications increase the risk of chronic kidney disease, and the presence of chronic kidney disease presents a challenge for HCV treatment in LT recipients. The aim of this study was to assess changes in glomerular filtration rates (GFRs) of LT recipients receiving HCV treatment. Methods: This is a retrospective study of LT patients who received HCV treatment between 2015 and $2016(n=60)$. The outcomes of interest were differences in serum creatinine levels and in GFR, measured at treatment initiation and at 24 weeks after treatment. The average age of the patients was 59 years-old, and $17 \%$ were cirrhotic and $67 \%$ were treatment-experienced. All patients received sofosbuvir/ledipasvir without ribavirin. Results: All patients achieved sustained virologic response at 12 weeks after treatment (SVR12). At baseline, 55\% of patients had GFR $<60 \mathrm{~mL} / \mathrm{min}$ per $1.73 \mathrm{~m}^{2}$. Among those patients, GFR did not change in $18 \%$, $33 \%$ had improved GFR, and $48 \%$ had worsened GFR. Up to $45 \%$ of the patients had a GFR $>60 \mathrm{~mL} / \mathrm{min}$ per $1.73 \mathrm{~m}^{2}$. Among those patients, GFR did not change in $81 \%$, and $19 \%$ had worsened GFR. In the entire cohort, $65 \%$ of patients had improved or stable GFR and 35\% had worsened GFR. The average change in serum creatinine between baseline and 24 weeks was $0.10(p=0.18)$. Conclusions: This study showed improved or unchanged GFR in $65 \%$ and worsened GFR in $35 \%$ of LT recipients who achieved SVR12. Worsening of GFR was more frequently encountered in those with impaired renal function at baseline. Caution should be used when treating HCV in LT recipients, especially those with baseline status of renal impairment.
\end{abstract}

Keywords: Hepatitis C; Renal function; Direct-acting antivirals; Liver transplant; Treatment.

Abbreviations: AASLD, Association for the Study of Liver Diseases; CKD, chronic kidney disease; DAA, direct-acting antiviral agent; GFR, glomerular filtration rate; $\mathrm{HCV}$, hepatitis C virus; LDV/SOF, ledipasvir/sofosbuvir; LT, liver transplant; MDRD, Modification of Diet in Renal Disease Study; RBV, ribavirin; SVR, sustained viral response.

Received: 10 April 2018; Revised: 17 June 2018; Accepted: 23 June 2018

* Correspondence to: John Romano, Department of Internal Medicine, School of Medicine, University of Alabama at Birmingham, BDB 327, $18087^{\text {th }}$ Ave South Birmingham, AL 35233, USA. Tel: +1-3156574626, E-mail: jaromano@uabmc.edu
Citation of this article: Shoreibah M, Romano J, Sims OT, Guo $Y$, Jones D, Venkata $\mathrm{K}$, et al. Effect of hepatitis $\mathrm{C}$ treatment on renal function in liver transplant patients. J Clin Transl Hepatol 2018;6(4):391-395. doi: 10.14218/JCTH.2018.00026.

\section{Introduction}

It is estimated that more than 5 million people have chronic hepatitis $\mathrm{C}$ virus (HCV) infection in the USA. ${ }^{1}$ Despite the availability of effective HCV treatments, it is predicted that advanced liver disease and its related mortality will continue to be a challenge until the year $2030 .^{2}$ In the year $2015, \mathrm{HCV}$ infection was the most common diagnosis amongst liver transplant (LT) recipients and the second most common indication for LT listing (26\%). ${ }^{3}$ According to the data from the Organ Procurement and Transplantation Network, there were 126,862 newly registered patients for LT between 1995 and 2010, and of those $41 \%$ had HCV. ${ }^{4}$

The vast majority of patients experience recurrence of $\mathrm{HCV}$ infection following LT. ${ }^{5}$ Histologic changes of chronic HCV infection can be seen in $70-90 \%$ of patients as early as 1 year postLT. $^{6}$ The median duration to progression of cirrhosis without treatment for patients with recurrent HCV infection postLT is 9.5 years. $^{7}$ The recurrence of HCV infection is associated with worse outcomes postLT, including increased graft failure and mortality. ${ }^{8-12}$ Fibrosing cholestatic hepatitis is a notorious form of HCV recurrence, occurring in up to $9 \%$, and may lead to graft failure and death. ${ }^{13}$

The newly introduced direct-acting antiviral agents (DAAs), administered with or without ribavirin (RBV), have revolutionized the treatment of recurrent HCV infection postLT, producing high sustained viral response (SVR) rates. ${ }^{14-16}$ This is important as HCV infection has been found to be a risk for developing renal insufficiency in the LT recipient. Renal insufficiency is common in LT recipients, occurring in $14 \%$ and $18 \%$ at 3 and 5 years postLT, respectively. ${ }^{17}$ In one study, most of the decline in glomerular filtration rate (GRF) occurred within the first 6 months following LT, with $30 \%$ or more decline occurring in $36 \%$ of the patients. ${ }^{18}$ At our institution, and probably in other centers, HCV recurrence is treated early on, where most of the decline of the GFR occurs, emphasizing further the need for data on safety of the currently available therapy regimens in the presence of renal insufficiency. 
The inevitability of HCV recurrence and renal insufficiency development creates a unique and challenging situation due to the limited data on the treatment of LT recipients, particularly in the presence of renal insufficiency. The American Association for the Study of Liver Diseases (AASLD) recommends the combination of ledipasvir/sofosbuvir (LDV/SOF) and RBV for 12 weeks for the treatment of HCV infection in LT recipients. ${ }^{19}$ We showed that the use of LDV/SOF without RBV is effective in achieving SVR. ${ }^{16}$ Since the data regarding the effect of this regimen on GFR in LT recipients is limited, we performed an ad hoc analysis to determine changes in the GFR with HCV treatment in LT recipients.

\section{Methods}

\section{Study design, patient population, and selection criteria}

We performed a retrospective analysis of the effect of HCV therapy for 12 or 24 weeks on the GFR in LT recipients. The study included $60 \mathrm{LT}$ recipients with recurrent $\mathrm{HCV}$ infection who were seen in our LT clinic between 2014 and 2016. Inclusion criteria were: age $>19$ years-old with recurrent $\mathrm{HCV}$ infection postLT. In 28 patients, the diagnosis of HCV recurrence was confirmed by liver biopsy findings. The other 32 patients were diagnosed with HCV recurrence according to the following criteria: positive serum PCR for HCV (Roche COBAS Ampliprep/TaqMan HCV RNA Test v2.0 >15 IU/mL) with elevated transaminases that could not be explained by other causes. The presence of cirrhosis was determined by documented radiologic imaging (ultrasound, computed tomography, or magnetic resonance imaging showing surface nodularity or architectural distortion consistent with cirrhosis) or liver biopsy findings (Metavir score $=4$ ). GFR was obtained using the Modification of Diet in Renal Disease Study (MDRD) formula (eGFR $=175 \times$ IDMS standardized serum creatinine$1.154 \times$ age- $0.203 \times 1.212$ [if black] $\times 0.742$ [if female]) .

The data collected through the electronic medical records included demographics (age, race and sex), laboratory results (GFR, albumin, platelets and alanine aminotransferase), HCV genotype, previous treatments, duration of HCV treatment, and types of immunosuppressive medications as well as their dosages before and after treatment.

We obtained approval from the University of Alabama's Institutional Review Board to conduct this study. Patients were treated with LDV/SOF $(90 \mathrm{mg} / 400 \mathrm{mg}$ ). The length of treatment was determined based on viral load, the presence of cirrhosis, and previous HCV treatment with inter provider variability. We enrolled 60 patients who met the inclusion criteria for this retrospective analysis.

\section{Statistical analysis}

Measures of central tendency and frequency distributions were used to characterize the sample. Frequency distributions were used to categorize the percentage of patients with normal and impaired renal functioning at baseline and to categorize the percentage of patients whose GRF improved, stayed the same, or worsened 24 weeks after treatment. Patients who experienced any numerical increase in GFR were grouped as improved, patients whose GFR did not increase or decrease were grouped as stayed the same (i.e. no change), and patients who experienced any numerical decrease in GFR were grouped as worsened. The paired samples $t$-test was used to compared creatinine levels before and at 24 weeks after treatment.

\section{Results}

The majority of patients were male $(70 \%)$, non-Hispanic White $(88 \%)$, and infected with genotype 1 a $(78 \%)$ (Table 1). The mean age was 59 years-old, and a small percentage of patients were cirrhotic $(17 \%)$. The mean number of months since liver transplantation was 69. All patients were prescribed LDV/SOF, and 45 patients (75\%) had 12 weeks of treatment, 12 patients $(20 \%)$ had 24 weeks of treatment, 2 patients $(3 \%)$ had 8 weeks of treatment and 1 patient (2\%) had 16 weeks of treatment.

At baseline, the mean creatinine level was $1.19(0.32)$, $27 \%$ of patients had normal renal function (GFR $<60 \mathrm{~mL} / \mathrm{min}$ per $1.73 \mathrm{~m}^{2}$ ), and $55 \%$ of patients had renal impairment (GFR $<60 \mathrm{~mL} / \mathrm{min}$ per $1.73 \mathrm{~m}^{2}$ ). Of those with renal impairment at baseline, GFR improved in $33 \%$ of patients, stayed the same in $18 \%$ of patients, and worsened in $48 \%$ of patients. Of those

Table 1. Baseline characteristics

\begin{tabular}{|c|c|}
\hline Characteristic & Value \\
\hline Study population, $n(\%)$ & $60(100)$ \\
\hline Age, mean (SD) & $59(7.24)$ \\
\hline $\begin{array}{l}\text { Sex, } n(\%) \\
\text { Female } \\
\text { Male }\end{array}$ & $\begin{array}{l}18(30) \\
42(70)\end{array}$ \\
\hline $\begin{array}{l}\text { Race/Ethnicity, } n(\%) \\
\text { Non-Hispanic White } \\
\text { African-American } \\
\text { Other }\end{array}$ & $\begin{array}{l}5(88) \\
6(10) \\
1(2)\end{array}$ \\
\hline $\begin{array}{l}\text { Genotype, } n(\%) \\
1 a \\
1 b\end{array}$ & $\begin{array}{l}47(78) \\
13(22)\end{array}$ \\
\hline Cirrhosis, $n(\%)$ & $10(17)$ \\
\hline $\begin{array}{l}\text { Months from transplantation, } \\
\text { mean (SD) }\end{array}$ & $68.399(68.76)$ \\
\hline Treatment naïve, $n(\%)$ & $33(55)$ \\
\hline $\begin{array}{l}\text { Regimen, } n(\%) \\
\text { Ledipasvir/sofosbuvir }\end{array}$ & $60(100)$ \\
\hline $\begin{array}{l}\text { Duration of treatment, } n(\%) \\
8 \text { weeks } \\
12 \text { weeks } \\
16 \text { weeks } \\
24 \text { weeks }\end{array}$ & $\begin{array}{l}2(3) \\
45(75) \\
1(2) \\
12(20)\end{array}$ \\
\hline Creatinine in $\mathrm{mg} / \mathrm{dL}$, mean (SD) & $1.19(0.32)$ \\
\hline $\begin{array}{l}\text { Renal impairment at baseline } \\
\text { GFR }<60 \mathrm{~mL} / \mathrm{min} \text { per } 1.73 \mathrm{~m}^{2}, n(\%)\end{array}$ & $33(55)$ \\
\hline $\begin{array}{l}\text { Renal function, } n(\%) \\
\text { Normal: GFR }>60 \\
\text { Mild impairment: (GFR }<60 \text { but } \geq 45 \\
\text { Moderate impairment: } \\
\text { GFR }<45 \text { but } \geq 30 \\
\text { Severe impairment: GFR }<30\end{array}$ & $\begin{array}{l}27(45) \\
21(35) \\
11(18) \\
1(2)\end{array}$ \\
\hline Bilirubin in $\mathrm{mg} / \mathrm{dL}$, mean (SD) & $1.26(1.48)$ \\
\hline Albumin in $\mathrm{g} / \mathrm{dL}$, mean (SD) & $3.84(0.47)$ \\
\hline ALT in $U / L$, mean (SD) & $63.03(41.48)$ \\
\hline Platelets as $10^{3} / \mu \mathrm{L}$, mean (SD) & $150.87(86.65)$ \\
\hline Hemoglobin in $\mathrm{g} / \mathrm{dL}$, mean (SD) & $13.21(1.91)$ \\
\hline
\end{tabular}


Table 2. Comparison of creatinine levels before treatment and 24 weeks after treatment

\begin{tabular}{llll}
\hline & $\begin{array}{l}\text { Before } \\
\text { treatment }\end{array}$ & $\begin{array}{l}\text { 24 weeks } \\
\text { posttreatment }\end{array}$ & $\begin{array}{l}\text { Statistical } \\
\text { significance }\end{array}$ \\
\hline $\begin{array}{l}\text { Number of } \\
\text { patients, } n\end{array}$ & 60 & 60 & \\
$\begin{array}{l}\text { Serum } \\
\text { creatinine } \\
\begin{array}{l}\text { as mg/dL, } \\
\text { mean (SD) }\end{array}\end{array}$ & $1.19(0.32)$ & $1.28(0.47)$ & $p=0.18$ \\
\hline
\end{tabular}

with normal renal functioning at baseline, GFR stayed the same in $81 \%$ of patients and worsened in $19 \%$ of patients. Altogether, $65 \%$ of the patients showed GFR improvement or staying the same and $35 \%$ of patients showed worsened GFR (Table 3).

There were no differences of statistical significance between patients' creatinine levels before and after treatment $(p=0.18)$ (Table 2). It is worth mentioning that the majority of patients in our cohort were on tacrolimus (88\%), with a median dose of $3 \mathrm{mg}$ (range: $0.5-18 \mathrm{mg}$ ) daily prior treatment compared to $2.5 \mathrm{mg}(0.5-14)$ daily after completion of treatment.

\section{Discussion}

The aim of this study was to assess changes in renal function of HCV LT patients receiving HCV treatment with DAAs. Several main findings emerged from this study. The majority of HCV LT patients who achieved SVR with LDV/SOF had posttreatment renal function improvement or stability. Similarly, the majority of patients with pretreatment renal impairment had renal function improvement or stability. HCV treatment did not significantly decrease creatinine levels. These findings are of importance in patients who receive LT, where the risk of renal insufficiency is increased.

Patients who had worsening of their renal function with treatment also had shown baseline renal impairment, thus caution should be taken while treating those patients. Omitting the use of RBV in those patients in particular would make the treatment less risky. Interestingly, our data showed a $100 \%$ SVR12 rate without the use of ribavirin. Similarly, data from the HCV-TARGET showed increased risk of worsening of renal functions with GFR $\leq 45 \mathrm{~mL} / \mathrm{min}$ per $1.73 \mathrm{~m}^{2} .{ }^{20}$

The data on use of LDV/SOF with and without RBV for treatment of recurrent HCV postLT is limited. In one study, more than $50 \%$ of the patients treated with LDV/SOF with RBV, had the latter discontinued. Anemia was the most common reason for the discontinuation of $\mathrm{RBV}$, and with that there was no significant change in the creatinine level before and after the completion of treatment. ${ }^{21}$ Another recent study looked at the course of 73 patients who received treatment with LDV/SOF without RBV for recurrent HCV infection after LT. Up to $82 \%$ had baseline chronic kidney disease (CKD stage 2 or 3 . The mean GFR was $66.8 \mathrm{~mL} / \mathrm{min}$ per $1.73 \mathrm{~m}^{2}$ at treatment initiation and never dropped below $64 \mathrm{~mL} / \mathrm{min}$ per $1.73 \mathrm{~m}^{2}$ during the observation period. ${ }^{22}$

SOF is an NS5B polymerase inhibitor, which is excreted through the kidneys. The SOF area under the curve was $61 \%$, $107 \%$ and $171 \%$ higher in mild, moderate and severe renal impairment, when compared to patients with normal GFR. The level of GS-331007, the SOF metabolite, was found to be markedly elevated in patients with end-stage renal disease. Thus far, the safety and efficacy of SOF in patients with severe renal impairment has not been well established. ${ }^{23}$ On the other hand, ledipasvir is an NS5A that is metabolized in the liver. A recent study evaluating the SOF-based therapy for patients with HCV infection and severe renal insufficiency, showed increased need for recombinant erythropoietin in those receiving RBV to maintain stable hemoglobin levels. ${ }^{24}$

$\mathrm{HCV}$ infection is associated with renal insufficiency and its complications, including increased risk of mortality. ${ }^{25}$ It has also been shown that HCV patients have up to a $23 \%$ risk of developing and/or having CKD. ${ }^{26}$ There is no study, to our knowledge, that addressed the effect of treatment with DAAs on renal function; however, data from the interferon era showed improved survival of patients with CKD and HCV who were treated for HCV compared to those who were not treated. ${ }^{27}$ PostLT, patients face the duo of inevitable HCV recurrence and the risk of developing CKD. The risk of developing CKD postLT is not only related to the presence of HCV infection but also to the use of calcineurin inhibitor-based immunosuppressive regimens, and the possibility of the development of diabetes and hypertension. ${ }^{17,28}$ A demographic shift is predicted in the future, where the number of older HCVinfected patients needing LT will be increased. ${ }^{4}$ With age being a risk factor for developing CKD and the demographic shift in the age of LT patients, one would anticipate increased incidence of CKD postLT in the future. ${ }^{29}$ In essence, we would be treating old patients with a higher risk of developing CKD early after LT, where most of the decline in GFR occurs.

The timing of HCV treatment in patients with advanced cirrhosis remains a topic of ongoing research and debate. A study suggested delaying HCV treatment in patients with MELD > 25 until LT is done, as a cost-effective strategy. ${ }^{30}$ Another study suggested MELD $<23$ as an optimum treatment threshold for patients with decompensated cirrhosis while awaiting $\mathrm{LT}^{31}$ For patients listed for $\mathrm{LT}$, we find it reasonable to treat those with MELD $<15$, individualizing the decision for

Table 3. Proportion of patients with renal improvement, no change and worsening before treatment and at 24 weeks after treatment

\begin{tabular}{lll}
\hline $\begin{array}{l}\text { Renal function before } \\
\text { treatment GFR in } \\
\mathrm{mL} / \mathrm{min} \text { per } 1.73 \mathrm{~m}^{2}\end{array}$ & $\begin{array}{l}\text { Improved GFR } \\
\text { at follow-up } \\
\text { of } 3-6 \text { months }\end{array}$ & $\begin{array}{l}\text { No change in } \\
\text { GFR at follow-up } \\
\text { of } 3-6 \text { months }\end{array}$ \\
\hline $\begin{array}{l}\text { Normal: GFR }>60 \\
27(45 \%)\end{array}$ & $0(0 \%)$ & $22(81 \%)$ \\
$\begin{array}{l}\text { Impaired: GFR }<60 \\
33(55 \%)\end{array}$ & $11(33 \%)$ & $6(18 \%)$ \\
Total $60(100 \%)$ & $11(18 \%)$ & $28(47 \%)$ \\
\hline
\end{tabular}


those with MELD of 15-25 and delaying the treatment for those with MELD $>25$ until after LT. ${ }^{32}$ There is a concern that treatment would deprive those patients with MELD $>25$ from accepting an HCV-positive donor liver, in addition to the fact that SVR rates seem to be better postLT when compared to decompensated cirrhotics prior to $\mathrm{LT}^{33}$ Studies have showed that successful treatment of HCV may lead to delisting of patients awaiting $\mathrm{LT}^{34-36}$ Some of those patients may not have a tangible improvement in their clinical condition. Another argument against treatment of HCV infection prior to LT in patients with advanced cirrhosis is the low likelihood that treatment would lead to improvement in their liver function. Additionally, the risk of NS5A resistance with treatment failure could limit and complicate treatment options post LT. ${ }^{37}$

Limitations of our study include the retrospective nature of the study and the small sample size. Further studies are needed to determine if there is any real risk of worsening renal function with HCV treatment in the setting of baseline renal insufficiency. Another improvement to the study design would be to control for confounders of changes to renal function, such as the degree of liver disease in the allograft or the effect of immunosuppression and preexisting comorbidities such as diabetes and hypertension. Our sample size was too small, and therefore lacked enough statistical power, to run these types of multivariate statistical analyses-limiting the study to a descriptive analysis. As such, although the majority of patients with posttreatment renal function worsening had impairment at baseline, we are unable to affirm that baseline impairment is an independent predictor of renal functioning worsening following DAA therapy.

Withstanding, this study explored a novel area of knowledge in a unique group of patients-those with recurrent HCV infection postLT. This study offered reassuring information regarding the safety of DAA therapy in postLT HCV patients. This study provided novel descriptive data on posttreatment renal functioning with DAA therapy in HCV LT patients, and the study findings can be used to help spur more focus on clinical research with this respective patient population.

\section{Conclusions}

The treatment of recurrent HCV infection postLT with LDV/ SOF was associated with stability or improvement in renal function in the majority of patients including some with baseline renal impairment. Caution should be exercised in patients with baseline renal impairment when treated with LDV/SOF, as some of those patients could develop worsening of their renal functions. Larger studies are needed to validate the safety of LDV/SOF in treatment of recurrent HCV infection postLT, particularly in patients with renal insufficiency.

\section{Conflict of interest}

Dr. Omar T. Sims has received research support from the National Institute on Alcohol and Alcoholism. Dr. Omar I. Massoud has received grants from Gilead Sciences. The remaining authors have no conflict of interests related to this publication.

\section{Author contributions}

Study concept and design (MS, JR, OTS, PF, OIM), acquisition of data (MS, DJ, KV, VK, JO, PF), statistical analysis (OTS, YG), analysis and interpretation of data (MS, JR, OTS, YG, OIM), drafting of the manuscript (MS, JR, OTS, OIM), critical revision of the manuscript (MS, JR, OTS, OIM), study supervision (MS, OIM).

\section{References}

[1] Armstrong GL, Wasley A, Simard EP, McQuillan GM, Kuhnert WL, Alter MJ. The prevalence of hepatitis C virus infection in the United States, 1999 through 2002. Ann Intern Med 2006;144:705-714 doi: 10.7326/0003-4819-14410-200605160-00004.

[2] Hatzakis A, Chulanov V, Gadano AC, Bergin C, Ben-Ari Z, Mossong J, et al. The present and future disease burden of hepatitis $C$ virus (HCV) infections with today's treatment paradigm - volume 2. J Viral Hepat 2015;22 Suppl 1: 26-45. doi: 10.1111/jvh.12351.

[3] Kim WR, Lake JR, Smith JM, Skeans MA, Schladt DP, Edwards EB, et al. OPTN/SRTR 2015 annual data report: Liver. Am J Transplant 2017;17 Suppl 1:174-251. doi: 10.1111/ajt.14126.

[4] Biggins SW, Bambha KM, Terrault NA, Inadomi J, Shiboski S, Dodge JL, et al. Projected future increase in aging hepatitis $C$ virus-infected liver transplant candidates: a potential effect of hepatocellular carcinoma. Liver Transpl 2012;18:1471-1478. doi: 10.1002/lt.23551.

[5] Wright TL, Donegan E, Hsu HH, Ferrell L, Lake JR, Kim M, et al. Recurrent and acquired hepatitis $C$ viral infection in liver transplant recipients. Gastroenterology 1992;103:317-322. doi: 10.1016/0016-5085(92)91129-R.

[6] Gane E. The natural history and outcome of liver transplantation in hepatitis C virus-infected recipients. Liver Transpl 2003;9:S28-S34. doi: 10.1053/jlts. 2003.50248.

[7] Berenguer M, Ferrell L, Watson J, Prieto M, Kim M, Rayón M, et al. HCV-related fibrosis progression following liver transplantation: increase in recent years. J Hepatol 2000;32:673-684.doi: 10.1016/S0168-8278(00)80231-7.

[8] Vinaixa C, Rubín A, Aguilera V, Berenguer M. Recurrence of hepatitis C after liver transplantation. Ann Gastroenterol 2013;26:304-313.

[9] Saxena V, Terrault N. Current management of hepatitis C virus: Regimens for peri-liver transplant patients. Clin Liver Dis 2015;19:669-688. doi: 10. 1016/j.cld.2015.06.007.

[10] Crespo G, Mariño Z, Navasa M, Forns X. Viral hepatitis in liver transplantation. Gastroenterology 2012;142:1373-1383.e1. doi: 10.1053/j.gastro. 2012.02.011.

[11] Forman LM, Lewis JD, Berlin JA, Feldman HI, Lucey MR. The association between hepatitis $C$ infection and survival after orthotopic liver transplantation. Gastroenterology 2002;122:889-896. doi: 10.1053/gast.2002.32418.

[12] Berenguer M. Natural history of recurrent hepatitis C. Liver Transpl 2002;8: S14-S18. doi: 10.1053/jits.2002.35781.

[13] Narang TK, Ahrens W, Russo MW. Post-liver transplant cholestatic hepatitis C: a systematic review of clinical and pathological findings and application of consensus criteria. Liver Transpl 2010;16:1228-1235. doi: 10.1002/It.22175.

[14] Kwo PY, Mantry PS, Coakley E, Te HS, Vargas HE, Brown R Jr, et al. An interferon-free antiviral regimen for HCV after liver transplantation. N Engl J Med 2014;371:2375-2382. doi: 10.1056/NEJMoa1408921.

[15] Charlton M, Everson GT, Flamm SL, Kumar P, Landis C, Brown RS Jr, et al. Ledipasvir and sofosbuvir plus ribavirin for treatment of HCV infection in patients with advanced liver disease. Gastroenterology 2015;149:649659. doi: $10.1053 / j$.gastro.2015.05.010.

[16] Shoreibah M, Orr J, Jones D, Zhang J, Venkata K, Massoud O. Ledipasvir/sofosbuvir without ribavirin is effective in the treatment of recurrent hepatitis $C$ virus infection post-liver transplant. Hepatol Int 2017;11:434-439. doi: 10. 1007/s12072-016-9778-6.

[17] Ojo AO, Held PJ, Port FK, Wolfe RA, Leichtman AB, Young EW, et al. Chronic renal failure after transplantation of a nonrenal organ. N Engl J Med 2003; 349:931-940. doi: 10.1056/NEJMoa021744.

[18] Corman SL, Coley KC, Schonder KS. Effect of long-term tacrolimus immunosuppression on renal function in liver transplant recipients. Pharmacotherapy 2006;26:1433-1437. doi: 10.1592/phco.26.10.1433.

[19] Hepatitis C. guidance: AASLD-IDSA recommendations for testing, managing, and treating adults infected with hepatitis $C$ virus. Hepatology $2015 ; 62$ : 932-954. doi: 10.1002/hep.27950.

[20] Saxena V, Koraishy FM, Sise ME, Lim JK, Schmidt M, Chung RT, et al. Safety and efficacy of sofosbuvir-containing regimens in hepatitis $C$-infected patients with impaired renal function. Liver Int 2016;36:807-816. doi: 10 . 1111/liv.13102.

[21] Ciesek S, Proske V, Otto B, Pischke S, Costa R, Lüthgehetmann M, et al. Efficacy and safety of sofosbuvir/ledipasvir for the treatment of patients with hepatitis $C$ virus re-infection after liver transplantation. Transpl Infect Dis 2016;18:326-332. doi: 10.1111/tid.12524.

[22] Pillai AA, Maheshwari R, Vora R, Norvell JP, Ford R, Parekh S, et al. Treatment of $\mathrm{HCV}$ infection in liver transplant recipients with ledipasvir and sofosbuvir without ribavirin. Aliment Pharmacol Ther 2017;45:1427-1432. doi: 10. 1111/apt.14059. 
[23] SOVLDI ${ }^{\text {Ò }}$ (safosbuvir) tablets, for oral use. Available from https://www. accessdata.fda.gov/drugsatfda_docs/label/2015/204671s002lbl.pdf.

[24] Dumortier J, Bailly F, Pageaux GP, Vallet-Pichard A, Radenne S, Habersetzer $\mathrm{F}$, et al. Sofosbuvir-based antiviral therapy in hepatitis $C$ virus patients with severe renal failure. Nephrol Dial Transplant 2017;32:2065-2071. doi: 10. 1093/ndt/gfw348.

[25] Molnar MZ, Alhourani HM, Wall BM, Lu JL, Streja E, Kalantar-Zadeh K, et al. Association of hepatitis $C$ viral infection with incidence and progression of chronic kidney disease in a large cohort of US veterans. Hepatology 2015 ; 61:1495-1502. doi: 10.1002/hep.27664.

[26] Park H, Adeyemi A, Henry L, Stepanova M, Younossi Z. A meta-analytic assessment of the risk of chronic kidney disease in patients with chronic hepatitis $C$ virus infection. J Viral Hepat 2015;22:897-905. doi: 10.1111/jvh.12413.

[27] Hsu YH, Hung PH, Muo CH, Tsai WC, Hsu CC, Kao CH. Interferon-based treatment of hepatitis $\mathrm{C}$ virus infection reduces all-cause mortality in patients with end-stage renal disease: An 8-year nationwide cohort study in Taiwan. Medicine (Baltimore) 2015;94:e2113. doi: 10.1097/MD.0000000000002113.

[28] Fabrizi F, Dixit V, Martin P, Messa P. Chronic kidney disease after liver transplantation: Recent evidence. Int J Artif Organs 2010;33:803-811. doi: 10. $1177 / 039139881003301105$.

[29] Kazancioğlu R. Risk factors for chronic kidney disease: an update. Kidney Int Suppl (2011) 2013;3:368-371. doi: 10.1038/kisup.2013.79.

[30] Njei B, McCarty TR, Fortune BE, Lim JK. Optimal timing for hepatitis C therapy in US patients eligible for liver transplantation: a cost-effectiveness analysis. Aliment Pharmacol Ther 2016;44:1090-1101. doi: 10.1111/apt. 13798.
[31] Chhatwal J, Samur S, Kues B, Ayer T, Roberts MS, Kanwal F, et al. Optimal timing of hepatitis $C$ treatment for patients on the liver transplant waiting list. Hepatology 2017;65:777-788. doi: 10.1002/hep.28926.

[32] Bunchorntavakul C, Reddy KR. HCV therapy in decompensated cirrhosis before or after liver transplantation: A paradoxical quandary. Am J Gastroenterol 2018;113:449-452. doi: 10.1038/ajg.2017.435.

[33] Verna EC, Brown RS Jr. HCV antiviral therapy in liver transplant candidates and recipients with renal insufficiency. Transplantation 2017;101:924-932. doi: 10.1097/TP.0000000000001688.

[34] Coilly A, Pageaux GP, Houssel-Debry P, Duvoux C, Radenne S, de Ledinghen V, et al. Improving liver function and delisting of patients awaiting liver transplantation for HCV cirrhosis: do we ask too much to DAA? Hepatology 2015; 62:257A.

[35] Pascasio JM, Vinaixa C, Ferrer MT, Colmenero J, Rubin A, Castells L, et al. Interferon (INF)-free antiviral therapy in cirrhotic patients infected with hepatitis $\mathrm{C}$ on the waiting list for liver transplantation. Efficacy and impact on delisting and liver function. J Hepatol 2016;64:S543. doi: 10.1016/S01688278(16)00969-7.

[36] Belli LS, Berenguer M, Cortesi PA, Strazzabosco M, Rockenschaub SR, Martini $S$, et al. Delisting of liver transplant candidates with chronic hepatitis C after viral eradication: A European study. J Hepatol 2016;65:524-531. doi: 10.1016/j.jhep.2016.05.010.

[37] Bunchorntavakul C, Reddy KR. Treat chronic hepatitis C virus infection in decompensated cirrhosis - pre- or post-liver transplantation? the ironic conundrum in the era of effective and well-tolerated therapy. J Viral Hepat 2016;23:408-418. doi: 10.1111/jvh.12534. 